\title{
Enteroendocrine changes facilitating weight loss following gastric bypass
}

\begin{abstract}
Obesity is reaching epidemic proportions and is accepted as the second leading preventable cause of death following smoking. As conventional weight loss methods have not been effective, bariatric surgery is the current treatment option for morbid obesity. The Roux en Y Gastric Bypass (RNYGBP) is accepted as the gold standard bariatric procedure for the long term management of morbid obesity. The mechanisms responsible for the cause and maintenance of weight loss after the operation have, however, not been clearly identified. The mechanical aspects of the operation fail to explain the results reported in the literature. Recent articles concentrate on the possible humoral factors as the cause of the success of the procedure. This review examines those hormonal changes following RNYGBP which are thought to be the main factors responsible for prolonged weight loss after the operation.
\end{abstract}

Volume 7 Issue 4 - 2017

\author{
Onur C Kutlu, Nestor De La Cruz Munoz \\ Division of Laparoendocopic and Bariartic Surgery, University of \\ Miami, Miller School of Medicine, USA
}

Correspondence: Nestor De La Cruz-Munoz, University of Miami, Division of Laparoendoscopic and Bariatric Surgery, 3650 NW 82nd Ave \#302, Doral, FL 33I66, USA, Tel 305-689-1910, Email ndelacruz@med.miami.edu

Received: June 09, 2017 | Published: September 05, 2017

Keywords: gastric bypass, diabetes, ghrelin, PYY, GLP, leptin, insulin, morbid obesity

\section{Introduction}

Obesity is a chronic, progressive and debilitating disease which affects psychological, biological and socials aspects of an individual's life. As obesity is now globally accepted as an epidemic, increasing number of surgical operations are being performed due to the high rates of failure of the available conventional therapy options. The number of operations performed for the treatment of morbid obesity has increased steadily during the last two decades to an estimated number of nearly 180,000 operations per year in the US. ${ }^{1,2}$ The majority of these procedures consist of various modifications of RNYGBP which is accepted as the gold standard procedure for the surgical treatment of morbid obesity. ${ }^{3}$

The RNYGBP procedure results in significant weight loss and a dramatic improvement in overall metabolic state of the patients suffering obesity by mechanisms that require elucidation., ${ }^{4,5}$ The technical aspects of the surgery may briefly be described as a combined restrictive malabsorbtive procedure, aiming to reduce the amount of food intake by the creation of a small gastric pouch of 25-50 ml's, a degree of outlet obstruction and diversion of the gastrointestinal tract in a Roux en Y configuration, bypassing up to $150 \mathrm{~cm}$ 's of the proximal gut in order to cause significant malabsorbtion of caloric nutrients. ${ }^{6}$

\section{RYNGBP - restriction of food ingestion}

The restrictive component of the operation is achieved by the creation of a separated gastric pouch by linear staplers. The pouch is usually created in a vertical configuration parallel to the lesser curve of the stomach, with an expected volume of 25-50 ml's depending on the technique used by the surgeon. The jejunal limb is then connected to the newly formed proximal gastric pouch by the use of either an intraluminal stapler of 21-23 mm's in diameter or $45 \mathrm{~mm}$ linear staplers or hand suturing over a $1.6 \mathrm{~cm}$ diameter tube. In all these techniques, the patient is expected to have an early feeling of fullness, delayed gastric emptying and to feel discomfort and thus prevent over eating by the small volume of the pouch. ${ }^{7-9}$

The idea of the restrictive component of the operation is similar to the commonly performed adjustable gastric banding (AGB) procedure. In the AGB, a silicon ring is wrapped around the proximal stomach forming a pouch of approximately $25 \mathrm{ml}$ 's over the ring which is expected to limit food intake. The size of the opening of the ring can be altered at a later stage to optimize the speed of the passage of food. ${ }^{10,11}$ While limiting food intake to induce weight loss by a restrictive procedure appears a logical proposition, an increasing number of reports highlight the high failure rates in the long term after AGB procedures. The papers which indicate successful results report an average of $9.3 \mathrm{~kg} / \mathrm{m}^{2}$ decrease in BMI in the long term, which would be inadequate to solve the problem of obesity in a patient with a pre-operative BMI more than $40 \mathrm{~kg} / \mathrm{m}^{2} .{ }^{12-14}$ The restrictive component of the RNYGBP is expected to be more prone to failures than AGB. Firstly, the stoma of the pouch formed in gastric bypass is wider than the opening of the proximal gastric pouch in the AGB, which should result in faster gastric emptying and shorter duration of fullness after meals. Secondly, while the size of the opening in the AGB is kept fixed by the power of the rigid silicone band, there is no reinforcement to prevent the dilation of the gastrojejunal stoma of the RNYGBP over time. ${ }^{15,16}$

Providing weight loss by restricting food intake, however, will likely fail in the long term. Research on mechano-chemical receptors of the GI tract have shown that ingestion of food high in volume and low in caloric value causes a transient decrease in body fat content. Following the initial weight loss, frequent but small sized meals will be ingested such that the energy balance remains constant, a situation frequently observed after pure restrictive operations. Studies have shown that volume detection has no major effect in body weight regulation. ${ }^{17,18}$

\section{RYNGBP - malabsorption of ingested food}

The malabsorbtive component of the operation may also contribute to the results achieved by the RNYGBP. The efferent end of the jejunum, after being transected approximately $50 \mathrm{~cm}$ 's distal to the ligament of Treitz, is connected to the newly formed proximal pouch by any of the techniques described previously. The afferent end is anastomosed $100 \mathrm{~cm}$ 's distally to the gastrojejunostomy, providing the continuum of the GI tract in a Roux en Y fashion. The main aim of this new rerouting of the GI tract is to decrease the length of the common limb where the nutrients are digested and absorbed by $150 \mathrm{~cm}$ 's to provide significant caloric malabsorbtion. ${ }^{6,7}$ Although inducing or accelerating 
weight loss via decreasing the absorptive surface may seem feasible, this approach has been proven to be effective only during the early postoperative period. Numerous recently published reports have shown that the adaptation mechanisms of the gut are successful in preventing malabsorption in a matter of weeks after gastric bypass. ${ }^{19,20}$ Both humans and laboratory animals which have been extensively investigated for postoperative absorption, exhibited either none or minimal signs of lipid, protein or carbohydrate maldigestion in stool samples, of which the results were comparable to the non-operated population. ${ }^{19-23}$

Consequently, the mechanical aspects of the operation fail to explain the results achieved by RNYGBP. An alternative explanation is provided by the possible involvement of altered gut hormones on hunger and energy regulation in patients who have undergone bariatric surgery.

\section{Ghrelin}

Since its relatively recent discovery in 1999, ghrelin has gained significant popularity among researchers. Being probably one of the most extensively studied hormones, ghrelin is a potent appetitestimulating peptide composed of 28 amino acids. ${ }^{24}$ Many tissues such as gonads, pancreas, lungs and jejunum have ghrelin-producing capabilities in trace amounts. The gastric fundus is, however, considered to be the major source of the circulating ghrelin, having $>10$ times more ghrelin producing cells than the second most active source which is the duodenum. ${ }^{25-29}$

Ghrelin is, thus far, the only known peptide released from the gastrointestinal tract that initiates food intake. ${ }^{30}$ Exogenous administration of ghrelin has been shown to induce voluntary eating and an overall increase in daily consumed calories in humans, non human primates and rodents. ${ }^{31-35}$ Normal healthy subjects exhibit daily alterations in ghrelin levels, a significant rise prior to a meal followed by a decrease after ingestion of food, a short duration cycle which is approximately completed in 1 hour. ${ }^{36-39}$ After the synthesis by the X/A-like cells, also called ghrelin cells, of the oxyntic glands of the gastric fundus, ghrelin is acylated with octanaoic acid, a process required for bioactivation and thought to be required for facilitation of passage through the blood brain barrier. ${ }^{40-42}$ Ghrelin exhibits its effect by stimulating specific neurons in the arcuate nucleus of the hypothalamus (ARC) ${ }^{43,44}$ Studies have shown that peripheral infusion of ghrelin leads to stimulation of arcuate neurons which stain for neuropeptide Y (NPY) and agouti related protein (Agrp). NPY and Agrp neurons are known to activate second order neurons that trigger feeding via the paraventricular nuclei of the hypothalamus. ${ }^{45-47}$ The vagus nerve may also be effective as a mediator/facilitator of the central effects of ghrelin. Although the exact mechanism is not known, the vagus may either directly stimulate the ARC in response to increased levels of peripheral ghrelin or synergistically augment the orexigenic effect of ghrelin. ${ }^{48,49}$ A recent study showed blunted orexigenic response to intraperioneal injection of ghrelin in rats after vagatomy. ${ }^{50}$

The effects of ghrelin have been well documented. Animals receiving anti-ghrelin antibodies or receptor blockers exhibited a decrease in hunger which resulted in body weight reduction. ${ }^{51,52}$ Administration of anti-NPY and Agrp antibodies to animals resulted in diminished response to peripheral infusion of ghrelin. Similar results have been achieved in knockout rats for genes coding NPY and Argp. ${ }^{42}$

Following the initial report by Cummings et al. ${ }^{43}$ on the reduction of ghrelin levels after RNYGBP, ghrelin levels have been studied by many researchers. Although the majority report an overall decrease or normalization of ghrelin levels after RNYGBP, some controversy remains regarding the effects of gastric bypass on this hormone..$^{27,53,54}$ The reported inconsistence may be attributed to either differences in surgical technique or alterations in handling and laboratory processing of the samples in different studies. ${ }^{55,56}$

A decrease in ghrelin levels after gastric bypass may be due to several possible mechanisms. Isolation of the fundus and the duodenum from nutrients will result in continuous stimulation of ghrelin-producing cells leading to a phenomenon known as "override inhibition" resulting in suppression of secretion..$^{53}$ Others report that the inevitable severing of gastric fundic nerve fibers during the gastric pouch creation, may attribute to the decreased ghrelin levels. ${ }^{57}$ Rapid passage of the nutrients in to the distal jejunum has also been proposed to decrease ghrelin secretion. ${ }^{38,53,58}$ While the controversy on post-operative ghrelin levels remains among authors, the majority of researchers report an overall decrease in plasma ghrelin levels following the RNYGBP.

\section{PYY}

PYY is a 36 amino acid peptide hormone secreted by the L-type endocrine cells of the gastrointestinal mucosa. In contrast to ghrelin, ${ }^{59}$ tissue concentrations of PYY remarkably increase distally in the gastrointestinal tract. The tissue concentration of PYY is nearly 600 times higher in the mucosa of the sigmoid colon compared to the gastric mucosa.$^{60} \mathrm{PYY}$ is present in circulation in two forms, the PYY (1-36) and the cleaved form of the hormone PYY (3-36) which is the end product of the truncation of the hormone by the enzyme Dipeptidyl Peptidase IV. ${ }^{61}$ Several studies have shown that nearly equal amounts of both forms are present within the mucosa and circulation. ${ }^{62,63}$

Current research suggests several mechanisms controlling the release of PYY into circulation. Animal and human studies have shown that the contact of fatty acids, carbohydrates and proteins with the distal gastrointestinal mucosa results in significant increases of PYY levels in the blood. ${ }^{4,62,63}$ This may be due to continuous monitorization of the luminal contents by L-cells. An increase in PYY levels shortly after duodenal contact with dietary nutrients has been demonstrated; ${ }^{63,64}$ this change may be attributed to either gut hormones secreted by the duodenum stimulating the L-Cells or via direct vagal activation of the PYY secreting glands of the distal gut. ${ }^{4,49}$ There may be other regulatory peptides or cytokines that regulate synthesis and secretion but the exact mechanisms are yet to be defined.

PYY in both forms directly crosses the blood brain barrier. ${ }^{65}$ The effects of the hormone are thought to be mediated via the Y type receptors in the hypothalamus. While direct intracelebral injection of PYY (136) results in increased appetite in rodents, ${ }^{66}$ peripheral injection has no effect on hunger perhaps due to conversion to PYY (3-36) by DPPIV. ${ }^{67}$ Research on the hormone have shown that the cleaved form, PYY (3-36), may be responsible for the appetite suppressing effects via Y2 receptors in the hypothalamus. ${ }^{68,69}$ Peripheral injection of PYY (3-36) results in decreased neuronal activity in the arcuate nucleus of the hypothalamus and reduced mRNA coding for NPY. Moreover, selectively blocking the $\mathrm{Y} 2$ receptors resulted in diminished appetite effects of PYY (3-36). ${ }^{70-72}$

Obesity have been shown to be associated with low basal PYY levels both in adults, children and in laboratory animals. ${ }^{73,74}$ The exact mechanisms of this phenomenon and whether obesity is a result of low levels of PYY synthesis are not known. Also, obese individuals exhibit blunted PYY response to meal ingestion. ${ }^{23,74-77}$ A study revealed that obese individuals required $100 \%$ more calorie ingestion to achieve PYY levels of healthy subjects. ${ }^{76}$ 
Numerous studies have been conducted to investigate the effects of RNYGBP on PYY levels. Basal and post-prandial PYY levels which are found to be low before the operation, have been shown to exhibit significant elevation (basal levels) and exhibit an early peak after meals. ${ }^{4,23,49,59}$ Similar results have been noted in rodents.$^{78,79}$. The exact mechanisms are not known, but may be attributed to earlier and more intense subjection of the distal gut mucosa to nutrients or, alternatively, be due to a decrease in levels of peptides such as leptin, thought to suppress PYY secretion and the hypothalamic response. ${ }^{80-82}$ In addition, constant high levels of DPP-IV have been identified after weight loss operations, ${ }^{80}$ a factor probably augmenting the anorexic effects of PYY itself.

\section{GLP |}

Glucagon like peptide 1 (GLP 1) is a cleaved product of the proglucagon molecule, secreted by the L cells of the gastrointestinal mucosa which also secrete PYY. ${ }^{83,84}$ As nutrients reach the distal bowel, GLP 1 is released into the circulation resulting in stimulation of insulin production of the pancreas, delaying of gastric emptying and central or peripheral suppression of appetite. ${ }^{85}$ GLP 1 is rapidly inactivated by DPP-IV enzyme which is the activator of PYY. ${ }^{86}$

The role of neural and other mechanisms are not clear on the release of GLP 1. As also seen in PYY response to nutrients, GLP 1 levels begin to rise shortly after meal ingestion, before nutrients reach the distal bowel. Although the duodenum is significantly poor in GLP-1 expressing cells compared to the distal bowel, it is know that intraluminal glucose stimulates the L cells causing a GLP-1 peak 20 minutes after ingestion. This effect is due continuous monitoring of the luminal contents by the L cells expressing gustducin coupled taste receptors. ${ }^{87}$ Why this early peak in response to intraluminal glucose stimuli is blunted in obese patients, is not known.

The exact mechanism by which the GLP causes its anorexic effects is also not clear. It is hypothesized that the GLP 1 receptor bearing neurons of the hind brain interact with the neural network of the hypothalamic nuclei and oxytocin containing neurons, through the dorsal vagal complex, result in inhibition of appetite. ${ }^{88,89}$ Studies have shown that obese patients compared to lean controls have lower GLP 1 levels in the fasting state, also the meal-induced GLP 1 peak is found to be suppressed in the obese population. ${ }^{90,91}$ The reason for this effect is not known, but may be attributed to desensitization of the $\mathrm{L}$ cells to continuous meal stimuli and hyperinsulinemia acting on the cellular and receptor levels. ${ }^{92}$

Several studies have shown that intracelebral injection of GLP 1 decreased food consumption of obese rats. ${ }^{30,93}$ Also, a decrease in appetite after peripheral GLP 1 administration in humans and rodents has been documented..$^{94-96}$ The anorexic effect of peripheral infusion of GLP 1 was also diminished in rats treated with intracelebral GLP 1 receptor antagonists. ${ }^{97}$ Long-term administration of Exendin-4, a GLP 1 agonist, effectively reduced appetite in obese rats, ${ }^{98}$ while prandial subcutaneous injection of GLP 1 in obese humans have been effective in reduction of body weight ${ }^{99}$ suggesting that increases in levels of GLP 1 may play a role in reducing body weight.

GLP 1 levels after RNYGBP has been investigated in many studies. While in the fasting state, GLP 1 levels displayed no significant difference between obese control groups and post-op RNYGBP patients, postprandial GLP 1 responses were, however, significantly higher in RNYGBP patients compared to BMI matched controls. ${ }^{5,100,101}$ Similar results have been identified in rodent studies supporting the role of RNYGBP on GLP 1 levels. ${ }^{102,103}$ The data presented in the published studies indicate a prominent role played by GLP 1 in inducing and maintaining prolonged weight loss after the RNYGBP.

\section{Leptin}

Leptin, discovered in 1994, is a hormone produced by adipocytes $^{104}$ and levels proportionally reflects the amount of lipid stored in the adipose tissue. ${ }^{105}$ It has been shown to be a mediator of the feedback loop between the hypothalamic nuclei and adipose tissue. ${ }^{106}$ Following the increase in body fat storage, the amount of circulating leptin rises, the hormone directly passes through the blood brain barrier and inhibits NPY release in the hypothalamic nuclei via specific leptin receptors promoting an anorexic state. ${ }^{107}$ This effect of the hormone has been well documented in rodents, primates as well as humans in many studies. ${ }^{104,107}$ Besides these central effects, leptin has been shown to promote insulin resistance in the adipocytes by altering insulin signaling. ${ }^{108}$ Peripheral administration of leptin to individuals with leptin deficiency and healthy controls leads to decreased appetite and weight loss in both groups, an effect more predominant in the leptin-deficient group. ${ }^{109,110}$ Studies have also shown that prevention of leptin decrease, in animals which are kept in fasting state, results in impaired food seeking behavior. ${ }^{111}$

The amount of weight-loss induced by leptin administration is higher than expected by the calorie deficit. Therefore, the effects of leptin on energy expenditure have been investigated and increased sympathetic discharge has been documented following intracerebral injection of leptin in primates, resulting in an increased metabolic rate. These findings support the effects of leptin on appetite control and metabolic rate. ${ }^{93,112,113}$

Leptin which once was thought to be a long-term mediator of appetite, has more recently been shown to be influenced by short fasting periods, without a significant reduction in body fat. It has also been shown to affect the short-term regulation of food intake. This change has been documented during reduction in caloric intake such as dieting, and increased leptin levels have been observed shortly after refeeding or overfeeding. ${ }^{114,115}$ This effect has been explained in studies documenting the effect of insulin and glucose which both have been shown to increase leptin gene expression and secretion. ${ }^{116}$

Obese individuals have significantly higher leptin levels compared to the lean population. This might be due to several reasons. Despite the amount of body fat, obese patients are in a hyperphagic state. Some studies have hypothesized that there might be a decrease in leptin transport through the blood brain barrier or receptor level impairment of leptin metabolism. ${ }^{30,93,116,117}$ The effects of RNYGBP on leptin levels have been investigated in humans and rodents early after the operation, before any significant weight loss occurred and decreased levels of leptin have been documented in these studies. ${ }^{54,100,118}$ This change may be attributed to either decreased food intake resulting in decreased glucose and insulin levels causing decreased leptin gene expression and synthesis. Some studies suggest that RNYGBY results in hormonal changes in hypothalamic center signaling, reprogramming the so called "thermostat" improving the response to leptin., 4119

\section{Insulin}

Obese patients are known to have high levels of insulin and glucose compared to the lean population. Insulin resistance, impaired $\beta$ cell response and hyperglycemia due to a constant inflammatory state in obesity have been thought to be responsible. ${ }^{120}$ The mechanisms for insulin resistance in the non-diabetic obese population are, however, 
not clearly understood. Ghrelin and leptin which are known to be elevated in the obese patient, have been shown to promote insulin resistance. ${ }^{4,108,119}$ Insulin known to result in fat deposition, the effects of high insulin levels are correlated to increased body fat content. ${ }^{121}$ But insulin is considered to be incapable of causing excess adiposity as seen in morbid obesity, ${ }^{122}$ and, in contrast, insulin has anorexic effects. Following the rise in blood, insulin transported through the blood brain barrier affects the hypothalamic centers and decreases NPY release resulting in a decreased appetite. ${ }^{68,123}$ This effect has been proven in studies where insulin is injected intracelebrally in primates and rodents which resulted in decreased food intake. ${ }^{124,125}$

Resolution of insulin resistance following RNYGBP has been documented. Some studies have reported amelioration of insulin response in a matter of weeks after the operation, prior to any significant weight loss. ${ }^{56,126-128}$ Several studies have investigated fasting and postprandial insulin levels following RNYGBP. One month after surgery, insulin levels have been found to be significantly lower than BMI-matched controls and similar to the lean population. ${ }^{129}$ Insulin response following meals has been shown to be significantly higher in the RNYGBP group compared to both obese and lean controls. ${ }^{100,130,131}$ An early increase in incretins such as GLP 1 and decreases in leptin and ghrelin levels are thought to be contributors to the resolution of insulin resistance and normoglycaemia but the exact mechanisms are still unknown. ${ }^{119,126}$

\section{Discussion}

More bariatric procedures are being performed as the rate of obesity increases in the population. The RNYGBP is considered the gold standard resulting in very successful outcomes compared to the other commonly performed procedures, vertical banded gastroplasty and the adjustable gastric banding. ${ }^{132}$ The effects resulting from the restrictive and malabsorptive components of the operation, however, cannot alone explain the weight reduction following the operation. ${ }^{14,15,19,22}$

Ghrelin, PYY, GLP 1, leptin, and insulin are the most commonly studied factors which may contribute to post-RNYGBP weight loss. Human studies have shown elevations in plasma levels of these hormones after operation leading to many assumptions about the hormonal effects of the RNYGBP (Figure 1). ${ }^{36,55,80,85,123}$ In animal and human studies, every one of these factors has been shown to decrease food intake when administered exogenously. These results support the hypotheses on the subject, but most studies examine the effects of these peptides separately and omit the fact that very complex, interconnected regulatory mechanisms exist in the body. When evaluated separately, each and every one of the factors involved in appetite regulation may be held responsible for weight reduction after surgery; however, looking at the big picture we can conclude that there is much more to be uncovered on the interactions of these peptides.

A reduction of ghrelin levels after RNYGBP, reported by some, has lead to an assumption that this hormone may be responsible for the effects of the operation..$^{53,133-135}$ Several other researchers, however, have reported unchanged or even increased levels. ${ }^{118,136}$ We believe that the role of surgery on ghrelin levels must be clarified by randomized trials in which standardized techniques are used. In addition, most of the studies report total ghrelin levels. The ratio of acylated ghrelin to total ghrelin levels is more appropriate, and results have shown a more prominent decrease in the active form of the hormone. ${ }^{4}$

PYY and GLP 1 levels have been found to be higher with an increased response to meals in the post-operative period, and may also explain appetite loss and early satiety after the operation. ${ }^{56,101,137}$ But numerous questions remain to be answered. GLP 1 is known to have inhibitory effects on PYY release, and an increase in plasma GLP 1 levels has been shown to decrease PYY release. ${ }^{138}$ DPP-IV, the enzyme required to convert the appetite stimulating form of PYY(136) to the anorexic PYY(3-36) has been found to be elevated following surgery. ${ }^{80}$ This may explain why the patients experience early satiety, but DPP-IV is the major enzyme responsible for the rapid degradation of GLP 1 to inactive forms. DPP IV deactivates GLP 1 in a matter of minutes diminishing its appetite suppressing and insulin secretory effects. ${ }^{85}$ We suggest that PYY and GLP 1 be studied in a large study group, the factors affecting the negative feedback loop between GLP 1 and PYY should be identified, the DPP-IV levels should also be studied while how the active forms of these potent anorexic hormones manage to co-exist in high amounts should be clarified.

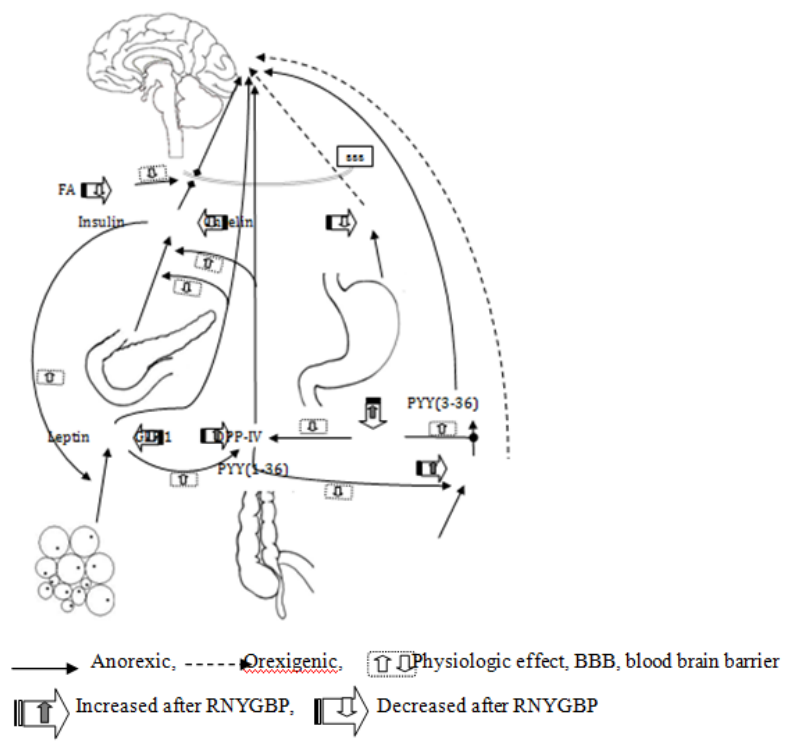

Figure I The effects of RNYGBP on the Enteroendocrine System.

Leptin levels are lower in the RNYGPB patients than matched BMI control groups. This change has been attributed to increased leptin sensitivity and an ameliorated response to the hormone. ${ }^{139,140}$ Leptin-GLP 1 interactions, however, are complex. While leptin is known to stimulate GLP 1 secretion from the distal bowel, ${ }^{141}$ GLP 1 has been shown to have no effect on leptin secretion. ${ }^{142}$ Leptin has also been shown to facilitate the GLP 1 response in the hypothalamic centers,${ }^{143,144}$ how the decreased levels of leptin affects this hormone after the operation has not been studied. The theory of an increased sensitivity should be studied by evaluation of NPY release and increase in metabolic rate in RNYGBP groups compared to obese controls.

Insulin metabolism in non-diabetic obese patients is known to be altered. In the reports which examined the effects of the RNYGBP on insulin and glucose metabolism, fasting insulin levels have been found to be lower compared to the matched BMI control groups. ${ }^{100,130,145}$ In the RNYGBP groups, a spike of exaggerated insulin response have been observed 15 minutes after a meal. ${ }^{100,146}$ Despite the over-secretion observed in the early postprandial period, the total insulin response (area under the curve) still remained significantly lower than the control groups. Some authors have associated the early insulin peak with the hypothalamic effects of insulin causing early satiety. ${ }^{100}$ Although this may be true, it is known that insulin's effects in the CNS requires a longer time frame; ${ }^{111}$ an early spike followed by fast return to normal levels may not be adequate for the proposed 
satiety effect of insulin. High fat diets and high levels of fatty acids in circulation are known to decrease the transport of insulin through the blood brain barrier and result in insulin resistance, RNYGBP may enhance the transport by decreasing the amount of fat ingested leading to low levels of plasma lipids. ${ }^{147,148}$ Insulin resistance has been known to resolve early after the operation. ${ }^{128,131}$ and transport to the CNS is likely to be enhanced, if this is the reason for the early hypothalamic response to insulin, more studies are needed to validate this hypothesis by administration of insulin after RNYGBP and observing the CNS effects.

It is obvious that there is no single simple answer to the question "What causes weight loss after RNYGBP". Our body is built for survival and it seems that maintaining energy stores has priority over preventing excessive weight gain in our programming. Mechanisms of controlling hunger, appetite and fat deposition are complex and remain to be precisely defined. The RNYGBP is accepted as a combined restrictive-malabsorbtive operation. Numerous studies have shown that mechanical components of this procedure are compensated soon after the operation, leading to the conclusion there is something "more than meets the eye" happening in the body. Although the exact mechanisms of enteroendocrine effects of the RNYGBP are not known, from the findings that we have we can clearly hypothesize that humoral effects are responsible for continued weight loss after the operation. Therefore we believe that the RNYGBP should be regarded as an endocrine operation of the gastrointestinal system for the treatment of obesity.

\section{Acknowledgments}

None.

\section{Conflicts of interest}

The authors declare no conflicts of interest.

\section{Funding}

None.

\section{References}

1. Buchwald H, Avidor Y, Braunwald E. Bariatric surgery:a systematic review and meta-analysis. JAMA. 2004;292(14):1724-1737.

2. Guijarro A, Suzuki S, Chen C. Characterization of weight loss and weight regain mechanisms after Roux-en-Y gastric bypass in rats. Am J Physiol Regul Integr Comp Physiol. 2007;293(4):1474-1489.

3. Steinbrook R. Surgery for severe obesity. $N$ Engl $J$ Med. 2004;350(11):1075-1079.

4. Korner J, Bessler M, Cirilo LJ. Effects of Roux-en-Y gastric bypass surgery on fasting and postprandial concentrations of plasma ghrelin, peptide YY, and insulin. J Clin Endocrinol Metab. 2005;90(1):359-365.

5. Laferrere B, Heshka S, Wang K. Incretin levels and effect are markedly enhanced 1 month after Roux-en-Y gastric bypass surgery in obese patients with type 2 diabetes. Diabetes Care. 2007;30(7):1709-1716.

6. Fobi MA, Lee H, Holness R, et al. Gastric bypass operation for obesity. World J Surg. 1998;22(9):925-935.

7. Higa KD, Boone KB, Ho T, et al. Laparoscopic Roux-en-Y gastric bypass for morbid obesity:technique and preliminary results of our first 400 patients. Arch Surg. 2000;135(9):1029-1033.

8. Himpens JM. The gastrojejunostomy in laparoscopic Roux-en-Y gastric bypass. Semin Laparosc Surg. 2014;11(3):171-177.
9. Korenkov M, Goh P, Yucel N, et al. Laparoscopic gastric bypass for morbid obesity with linear gastroenterostomy. Obes Surg. $2003 ; 13(3): 360-363$

10. Forsell P, Hallberg D, Hellers G. Gastric Banding for Morbid Obesity: Initial Experience with a New Adjustable Band. Obes Surg. 1993;(4):369-374.

11. Forsell P, Hallberg D, Hellers GA. Gastric Band with Adjustable Inner Diameter for Obesity Surgery:Preliminary Studies. Obes Surg. 1993;3(3):303-306

12. Angrisani L, Lorenzo M, Borrelli V. Laparoscopic adjustable gastric banding versus Roux-en-Y gastric bypass:5-year results of a prospective randomized trial. Surg Obes Relat Dis. 2007;3(2):127-132.

13. Himpens J, Dapri G, Cadiere GB. A prospective randomized study between laparoscopic gastric banding and laparoscopic isolated sleeve gastrectomy:results after 1 and 3 years. Obes Surg. 2006;16(11):14501456.

14. Suter M, Calmes JM, Paroz A, et al. A 10-year experience with laparoscopic gastric banding for morbid obesity: high long-term complication and failure rates. Obes Surg. 2006;16(7):829-835.

15. Spaulding L. Treatment of dilated gastrojejunostomy with sclerotherapy. Obes Surg. 2003;13(2):254-257.

16. Thompson CC, Slattery J, Bundga ME, et al. Peroral endoscopic reduction of dilated gastrojejunal anastomosis after Roux-en-Y gastric bypass:a possible new option for patients with weight regain. Surg Endosc. 2006;20(11):1744-1748.

17. Smith M, Duffy M. The effects of intragastric injection of various substances on subsequent bar-pressing. J Comp Physiol Psychol. 1955;48(5):387-391.

18. Adolph EF. Urges to eat and drink in rats. Am J Physiol. 1947;151(1):110

19. MacLean LD, Rhode BM, Nohr CW. Long-nor short-limb gastric bypass? J Gastrointest Surg. 2001;5(5):525-530.

20. Naslund I. Gastric bypass versus gastroplasty. A prospective study of differences in two surgical procedures for morbid obesity. Acta Chir Scand. 1987;Suppl 536:1-60.

21. Brolin RE, LaMarca LB, Kenler HA, et al. Malabsorptive gastric bypass in patients with superobesity. J Gastrointest Surg March. 2002;6(2):195203

22. Faraj M, Jones P, Sniderman AD, et al. Enhanced dietary fat clearance in postobese women. J Lipid Res. 2001;42(4):571-580.

23. le Roux CW, Aylwin SJ, Batterham RL. Gut hormone profiles following bariatric surgery favor an anorectic state, facilitate weight loss, and improve metabolic parameters. Ann Surg. 2001;243(1):108-114.

24. Howard AD, Feighner SD, Cully DF. A receptor in pituitary and hypothalamus that functions in growth hormone release. Science. 1996;273(5277):974-977.

25. Date $\mathrm{Y}$, Kojima $\mathrm{M}$, Hosoda $\mathrm{H}$, et al. a novel growth hormonereleasing acylated peptide, is synthesized in a distinct endocrine cell type in the gastrointestinal tracts of rats and humans. Endocrinology. 2000;141(11):4255-4261.

26. Kojima M, Hosoda H, Date Y. Ghrelin is a growth-hormone-releasing acylated peptide from stomach. Nature. 1999;402(6762):656-660.

27. Lee H, Te C, Koshy S. Does ghrelin really matter after bariatric surgery? Surg Obes Relat Dis. 2006;2(5):538-548.

28. van der Lely AJ, Tschop M, Heiman ML, et al. Biological, physiological, pathophysiological, and pharmacological aspects of ghrelin. Endocr Rev. 2004;25(3):426-457. 
29. Gnanapavan S, Kola B, Bustin SA. The tissue distribution of the mRNA of ghrelin and subtypes of its receptor, GHS-R, in humans. J Clin Endocrinol Metab. 2002;87(6):2988.

30. Strader AD, Woods SC. Gastrointestinal hormones and food intake. Gastroenterology. 2005;128(1):175-191.

31. Neary NM, Small CJ, Wren AM. Ghrelin increases energy intake in cancer patients with impaired appetite:acute, randomized, placebocontrolled trial. J Clin Endocrinol Metab. 2004;89(6):2832-2836.

32. Tschop M, Weyer C, Tataranni PA. Circulating ghrelin levels are decreased in human obesity. Diabetes. 2001;50(4):707-709.

33. Wren AM, Small CJ, Ward HL. The novel hypothalamic peptide ghrelin stimulates food intake and growth hormone secretion. Endocrinology. 2000;141(11):4325-4328.

34. Wren AM, Small CJ, Fribbens CV. The hypothalamic mechanisms of the hypophysiotropic action of ghrelin. Neuroendocrinology. 2002;76(5):316-324.

35. Cummings DE, Shannon MH. Roles for ghrelin in the regulation of appetite and body weight. Arch Surg. 2003;138(4):389-396.

36. Asakawa A, Inui A, Kaga T. Ghrelin is an appetite-stimulatory signal from stomach with structural resemblance to motilin. Gastroenterology. 2001;120(2):337-345.

37. Tschop M, Wawarta R, Riepl RL. Post-prandial decrease of circulating human ghrelin levels. J Endocrinol Invest. 2001;24(6):RC19-RC21.

38. Williams DL, Cummings DE, Grill HJ, et al. Meal-related ghrelin suppression requires postgastric feedback. Endocrinology. 2003;144(7):2765-2767.

39. Cummings DE, Purnell JQ, Frayo RS. A preprandial rise in plasma ghrelin levels suggests a role in meal initiation in humans. Diabetes. 2001;50(8):1714-1719.

40. Banks WA, Tschop M, Robinson SM, et al. Extent and direction of ghrelin transport across the blood-brain barrier is determined by its unique primary stru.cture. J Pharmacol Exp Ther. 2002;302(2):822-827.

41. Kojima M, Hosoda H, Date Y. Ghrelin is a growth-hormone-releasing acylated peptide from stomach. Nature. 1999;402(6762):656-660.

42. Nakazato M, Murakami N, Date Y. A role for ghrelin in the central regulation of feeding. Nature. 2001;409(6817):194-198.

43. Tschop M, Smiley DL, Heiman ML. Ghrelin induces adiposity in rodents. Nature. 2000;407(6806):908-913.

44. Wren AM, Seal LJ, Cohen MA. Ghrelin enhances appetite and increases food intake in humans. J Clin Endocrinol Metab. 2001;86(12):5992.

45. Broberger C, Johansen J, Johansson C. The neuropeptide Y/agouti gene-related protein (AGRP) brain circuitry in normal, anorectic, and monosodium glutamate-treated mice. Proc Natl Acad Sci USA. 1998;95(25):15043-15048.

46. St Pierre DH, Wang L, Tache Y. Ghrelin:a novel player in the gut-brain regulation of growth hormone and energy balance. News Physiol Sci. 2003;18:242-246.

47. Wang L, Saint Pierre DH, Tache Y. Peripheral ghrelin selectively increases Fos expression in neuropeptide $\mathrm{Y}$ - synthesizing neurons in mouse hypothalamic arcuate nucleus. Neurosci Lett. 2002;325(1):4751.

48. Date Y, Murakami N, Toshinai K. The role of the gastric afferent vagal nerve in ghrelin-induced feeding and growth hormone secretion in rats. Gastroenterology. 2002;123(4):1120-1128.

49. Neary NM, Small CJ, Bloom SR. Gut and mind. Gut. 2003;52(7):918921.

50. Date Y, Murakami N, Toshinai K. The role of the gastric afferent vagal nerve in ghrelin-induced feeding and growth hormone secretion in rats. Gastroenterology. 2002;123(4):1120-1128.

51. Bagnasco M, Tulipano G, Melis MR. Endogenous ghrelin is an orexigenic peptide acting in the arcuate nucleus in response to fasting. Regul Pept. 2003;111(1-3):161-167.

52. Carlson MJ, Cummings DE. Prospects for an anti-ghrelin vaccine to treat obesity. Mol Interv. 2006;6(5):249-252.

53. Cummings DE, Weigle DS, Frayo RS. Plasma ghrelin levels after diet-induced weight loss or gastric bypass surgery. $N$ Engl $\mathrm{J} \mathrm{Med}$. 2002;346(21):1623-16230.

54. Kotidis EV, Koliakos GG, Baltzopoulos VG. Serum ghrelin, leptin and adiponectin levels before and after weight loss:comparison of three methods of treatment-a prospective study. Obes Surg. 2006;16(11):1425-1432.

55. Cummings DE, Shannon MH. Ghrelin and gastric bypass:is there a hormonal contribution to surgical weight loss? J Clin Endocrinol Metab. 2003;88(7):2999-3002.

56. Whitson BA, Leslie DB, Kellogg TA. Entero-endocrine changes after gastric bypass in diabetic and nondiabetic patients:a preliminary study. $J$ Surg Res. 2007;141(1):31-39.

57. Williams DL, Grill HJ, Cummings DE, et al. Vagotomy dissociates short- and long-term controls of circulating ghrelin. Endocrinology. 2003;144(12):5184-5187.

58. Rubino F, Zizzari P, Tomasetto C. The role of the small bowel in the regulation of circulating ghrelin levels and food intake in the obese Zucker rat. Endocrinology. 2005;146(4):1745-1751.

59. Hanusch Enserer U, Roden M. News in gut-brain communication:a role of peptide YY (PYY) in human obesity and following bariatric surgery? Eur J Clin Invest. 2005;35(7):425-430.

60. Ferri GL, Adrian TE, Allen JM. Intramural distribution of regulatory peptides in the sigmoid-recto-anal region of the human gut. Gut. 1988;29(6):762-768.

61. Grandt D, Dahms P, Schimiczek M. [Proteolytic processing by dipeptidyl aminopeptidase IV generates receptor selectivity for peptide YY (PYY)]. Med Klin (Munich). 1993;88(3):143-145.

62. Grandt D, Schimiczek M, Beglinger C. Two molecular forms of peptide YY (PYY) are abundant in human blood:characterization of a radioimmunoassay recognizing PYY 1-36 and PYY 3-36. Regul Pept. 1994;51(2):151-159.

63. Ballantyne GH. Peptide YY (1-36) and peptide YY (3-36):Part I. Distribution, release and actions. Obes Surg. 2006;16(5):651-658.

64. Anini Y, Fu-Cheng X, Cuber JC. Comparison of the postprandial release of peptide YY and proglucagon-derived peptides in the rat. Pflugers Arch. 1999;438(3):299-306.

65. Nonaka N, Shioda S, Niehoff ML, et al. Characterization of blood-brain barrier permeability to PYY3-36 in the mouse. J Pharmacol Exp Ther. 2003;306(3):948-953.

66. Hagan MM. Peptide YY: a key mediator of orexigenic behavior. Peptides. 2002;23(2):377-382.

67. Sloth B, Davidsen L, Holst JJ. Effect of subcutaneous injections of PYY1-36 and PYY3-36 on appetite, ad libitum energy intake, and plasma free fatty acid concentration in obese males. Am J Physiol Endocrinol Metab. 2007;293(2):E604-E609.

68. Schwartz MW, Woods SC, Porte D. Central nervous system control of food intake. Nature. 2000;404(6778):661-671.

69. Woods SC. Gastrointestinal satiety signals I. An overview of gastrointestinal signals that influence food intake. Am J Physiol Gastrointest Liver Physiol. 2004;286(1):G7-G13. 
70. Batterham RL, Cowley MA, Small CJ. Gut hormone PYY(3-36) physiologically inhibits food intake. Nature. 2002;418(6898):650-654.

71. Larhammar D. Structural diversity of receptors for neuropeptide Y, peptide YY and pancreatic polypeptide. Regul Pept. 1996;65(3):165174.

72. Batterham RL, Bloom SR. The gut hormone peptide YY regulates appetite. Ann N Y Acad Sci. 2003;994:162-168.

73. Alvarez Bartolomé M, Borque M, Martinez-Sarmiento J, et al. Peptide YY secretion in morbidly obese patients before and after vertical banded gastroplasty. Obes Surg. 2002;12(3):324-327.

74. Batterham RL, Cohen MA, Ellis SM, et al. Inhibition of food intake in obese subjects by peptide YY3-36. N Engl J Med. 2003;349(10):941948.

75. Alvarez Bartolomé M, Borque M, Martinez-Sarmiento J, et al. Peptide YY secretion in morbidly obese patients before and after vertical banded gastroplasty. Obes Surg. 2002;12(3):324-327.

76. le Roux CW, Batterham RL, Aylwin SJ, et al. Attenuated peptide YY release in obese subjects is associated with reduced satiety. Endocrinology. 2006;147(1):3-8.

77. Murphy KG, Dhillo WS, Bloom SR. Gut peptides in the regulation of food intake and energy homeostasis. Endocr Rev. 2006;27(7):719-727.

78. Koopmans HS, Ferri GL, Sarson DL, et al. The effects of ileal transposition and jejunoileal bypass on food intake and GI hormone levels in rats. Physiol Behav. 1984;33(4):601-609.

79. Cummings DE, Overduin J, Foster-Schubert KE, et al. Role of the bypassed proximal intestine in the anti-diabetic effects of bariatric surgery. Surg Obes Relat Dis. 2007;3(2):109-115.

80. Ballantyne GH. Peptide YY(1-36) and peptide YY(3-36):Part II Changes after gastrointestinal surgery and bariatric surgery. Obes Surg. 2006;16(6):795-803.

81. Rosenbaum M, Nicolson M, Hirsch J, et al. Effects of weight change on plasma leptin concentrations and energy expenditure. J Clin Endocrinol Metab. 1997;82(11):3647-3654.

82. Pinilla L, Fernandez-Fernandez R, Vigo E, et al. Stimulatory effect of PYY-(3-36) on gonadotropin secretion is potentiated in fasted rats. Am J Physiol Endocrinol Metab. 2006;290(6):E1162-E1171.

83. Eissele R, Göke R, Willemer S, et al. Glucagon-like peptide-1 cells in the gastrointestinal tract and pancreas of rat, pig and man. Eur J Clin Invest. 1992;22(4):283-291.

84. Rouille Y, Martin S, Steiner DF. Differential processing of proglucagon by the subtilisin-like prohormone convertases PC2 and PC3 to generate either glucagon or glucagon-like peptide. J Biol Chem. 1992;270(44):26488-26496.

85. Frezza EE, Wachtel MS, Chiriva-Internati M. The multiple faces of glucagon-like peptide-1--obesity, appetite, and stress:what is next? A review. Dig Dis Sci. 2007;52(3):643-649.

86. Kieffer TJ, McIntosh CH, Pederson RA. Degradation of glucosedependent insulinotropic polypeptide and truncated glucagon-like peptide 1 in vitro and in vivo by dipeptidyl peptidase IV. Endocrinology. 1995;136(8):3585-3596.

87. Jang HJ, Kokrashvili Z, Theodorakis MJ, et al. Gut-expressed gustducin and taste receptors regulate secretion of glucagon-like peptide-1. Proc Natl Acad Sci U S A. 2007;104(38):15069-15074.

88. Yamamoto H, Kishi T, Lee CE, et al. Glucagon-like peptide-1responsive catecholamine neurons in the area postrema link peripheral glucagon-like peptide-1 with central autonomic control sites. $J$ Neurosci. 2003;23(7):2939-2946.

89. Cohen MA, Ellis SM, Le Roux CW, et al. Oxyntomodulin suppresses appetite and reduces food intake in humans. $J$ Clin Endocrinol Metab. 2003;88(10):4696-4701.

90. Ranganath LR, Beety JM, Morgan LM, et al. Attenuated GLP-1 secretion in obesity:cause or consequence? Gut. 1996;38(6):916-919.

91. Tomasik PJ, Sztefko K, Malek A. GLP-1 as a satiety factor in children with eating disorders. Horm Metab Res. 2002;34(2):77-80.

92. Gareth E Lim, Patricia L Brubaker. Glucagon-Like Peptide 1 Secretion by the L-Cell. Diabetes. 2006;55(Supplement 2):S70-S77.

93. Blevins JE, Schwartz MW, Baskin DG, Peptide signals regulating food intake and energy homeostasis. Can J Physiol Pharmacol. 2002;80(5):396-406.

94. Larsen PJ, Tang-Christensen M, Jessop DS. Central administration of glucagon-like peptide-1 activates hypothalamic neuroendocrine neurons in the rat. Endocrinology. 1997;138(10):4445-4455.

95. Baggio LL, Huang Q, Brown TJ, et al. Oxyntomodulin and glucagonlike peptide- 1 differentially regulate murine food intake and energy expenditure. Gastroenterology . 2004;127(2):546-558.

96. Baggio LL, Huang Q, Brown TJ, et al. A recombinant human glucagonlike peptide (GLP)-1-albumin protein (albugon) mimics peptidergic activation of GLP-1 receptor-dependent pathways coupled with satiety, gastrointestinal motility, and glucose homeostasis. Diabetes. 2004;53(9):2492-2500.

97. Meeran K, O'Shea D, Edwards CM, etal. Repeated intracerebroventricular administration of glucagon-like peptide-1-(7-36) amide or exendin(9-39) alters body weight in the rat. Endocrinology. 1999;140(1):244 250.

98. Larsen PJ, Fledelius C, Knudsen LB, et al. Systemic administration of the long-acting GLP-1 derivative NN2211 induces lasting and reversible weight loss in both normal and obese rats. Diabetes. 2001;50(11):2530 2539 .

99. Näslund E, King N, Mansten S, et al. Prandial subcutaneous injections of glucagon-like peptide-1 cause weight loss in obese human subjects. Br J Nutr. 2004;91(3):439-446.

100. Borg CM, le Roux CW, Ghatei MA, et al. Progressive rise in gut hormone levels after Roux-en-Y gastric bypass suggests gut adaptation and explains altered satiety. Br J Surg. 2006;93(2):210-215.

101. Morínigo R, Moizé V, Musri M, et al. Glucagon-like peptide-1, peptide YY, hunger, and satiety after gastric bypass surgery in morbidly obese subjects. J Clin Endocrinol Metab. 2006;91(5):1735-1740.

102. Rubino F, Forgione A, Cummings DE, et al. The mechanism of diabetes control after gastrointestinal bypass surgery reveals a role of the proximal small intestine in the pathophysiology of type 2 diabetes. Ann Surg. 2006;244(5):741-749.

103. Rubino F, Gagner M, Gentileschi P, et al. The early effect of the Rouxen-Y gastric bypass on hormones involved in body weight regulation and glucose metabolism. Ann Surg. 2004;240(2):236-242.

104. Halaas JL, Friedman JM. Leptin and its receptor. J Endocrinol. $1997 ; 155(2): 215-216$

105. Cohen SL, Halaas JL, Friedman JM, et al. Human leptin characterization. Nature. 1996;382(6592):589.

106. Rohner-Jeanrenaud F, Cusin I, Sainsbury A, et al. The loop system between neuropeptide $\mathrm{Y}$ and leptin in normal and obese rodents. Horm Metab Res. 1996;28(12):642-648.

107. Friedman JM, Halaas JL. Leptin and the regulation of body weight in mammals. Nature. 1998;395(6704):763-770.

108. Cases JA, Gabriely I, Ma XH, et al. Physiological increase in plasma leptin markedly inhibits insulin secretion in vivo. Diabetes. 2001;50(2):348-352. 
109. Farooqi IS, Jebb SA, Langmack G, et al. Effects of recombinant leptin therapy in a child with congenital leptin deficiency. $N$ Engl J Med. 1999;341(12):879-884.

110. Farooqi IS, Keogh JM, Kamath S, et al. Partial leptin deficiency and human adiposity. Nature. 2001;414(6859):34-35.

111. Havel PJ. Peripheral signals conveying metabolic information to the brain:short-term and long-term regulation of food intake and energy homeostasis. Exp Biol Med (Maywood). 226(11):963-977.

112. Baskin DG, Blevins JE, Schwartz MW. How the brain regulates food intake and body weight:the role of leptin. J Pediatr Endocrinol Metab. 2001;14 Suppl 6:1417-1429.

113. Scarpace PJ, Matheny M, Pollock BH, et al. Leptin increases uncoupling protein expression and energy expenditure. Am J Physiol. 1997;273(1 Pt 1):E226-E230.

114. Boden G, Chen X, Mozzoli M, et al. Effect of fasting on serum leptin in normal human subjects. J Clin Endocrinol Metab. 1996;81(9):34193423 .

115. Weigle DS, Duell PB, Connor WE, et al. Effect of fasting, refeeding, and dietary fat restriction on plasma leptin levels. J Clin Endocrinol Metab. 1997;82(2):561-565.

116. Mizuno TM, Bergen $H$, Funabashi $T$, et al. Obese gene expression:reduction by fasting and stimulation by insulin and glucose in lean mice, and persistent elevation in acquired (diet-induced) and genetic (yellow agouti) obesity. Proc Natl Acad Sci U S A. 1996;93(8):3434-3438.

117. Caro JF, Kolaczynski JW, Nyce MR, et al. Decreased cerebrospinalfluid/serum leptin ratio in obesity:a possible mechanism for leptin resistance. Lancet. 1996;348(9021):159-161.

118. Faraj M, Havel PJ, Phélis S, et al. Plasma acylation-stimulating protein, adiponectin, leptin, and ghrelin before and after weight loss induced by gastric bypass surgery in morbidly obese subjects. $J$ Clin Endocrinol Metab. 2003;88(4):1594-1602.

119. Rubino F, Gagner M, Gentileschi P, et al. The early effect of the Rouxen-Y gastric bypass on hormones involved in body weight regulation and glucose metabolism. Ann Surg. 2004;240(2):236-242.

120. Ramos EJ, Xu Y, Romanova I, et al. Is obesity an inflammatory disease? Surgery. 2003;34(2):329-335

121. Blüher M, Michael MD, Peroni OD, et al. Adipose tissue selective insulin receptor knockout protects against obesity and obesity-related glucose intolerance. Dev Cell. 2002;3(1):25-38.

122. Schwartz MW, Boyko EJ, Kahn SE, et al. Reduced insulin secretion:an independent predictor of body weight gain. J Clin Endocrinol Metab. 1995;80(5):1571-1576.

123. Baskin DG, Figlewicz Lattemann D, Seeley RJ, et al. Insulin and leptin:dual adiposity signals to the brain for the regulation of food intake and body weight. Brain Res. 1999;848(1-2):114-123.

124. Sipols AJ, Baskin DG, Schwartz MW. Effect of intracerebroventricular insulin infusion on diabetic hyperphagia and hypothalamic neuropeptide gene expression. Diabetes. 1995;44(2):147-151.

125. Schwartz MW, Marks JL, Sipols AJ, et al. Central insulin administration reduces neuropeptide $\mathrm{Y}$ mRNA expression in the arcuate nucleus of food-deprived lean $(\mathrm{Fa} / \mathrm{Fa})$ but not obese (fa/fa) Zucker rats. Endocrinology. 1991;128(5):2645-2647.

126. Rubino F. Bariatric surgery:effects on glucose homeostasis. Curr Opin Clin Nutr Metab Care. 2006;9(4):497-507.

127. Edén Engström B, Burman P, Holdstock C, et al. Effects of gastric bypass on the GH/IGF-I axis in severe obesity - and a comparison with GH deficiency. Eur J Endocrinol. 2006;154(1):53-59.

128. Smith SC, Edwards CB, Goodman GN. Changes in Diabetic Management After Roux-en-Y Gastric Bypass. Obes Surg. 1996;6(4):345-348.
129. Polyzogopoulou EV, Kalfarentzos F, Vagenakis AG, et al. Restoration of euglycemia and normal acute insulin response to glucose in obese subjects with type 2 diabetes following bariatric surgery. Diabetes. 2003;52(5):1098-1103.

130. Pories WJ, Swanson MS, MacDonald KG, et al. Who would have thought it? An operation proves to be the most effective therapy for adult-onset diabetes mellitus. Ann Surg. 1995;222(3):339-350.

131. Schauer PR, Burguera B, Ikramuddin S, et al. Effect of laparoscopic Roux-en Y gastric bypass on type 2 diabetes mellitus. Ann Surg. 2003;238(4):467-484.

132. Johnson W, DeMaria E. Surgical treatment of obesity. Curr Treat Options Gastroenterol. 2006;9(2):167-174.

133. Geloneze B, Tambascia MA, Pilla VF, et al. Ghrelin: a gut-brain hormone:effect of gastric bypass surgery. Obes Surg. 2003;13(1):17-22.

134. Fruhbeck G, Rotellar F, Hernandez-Lizoain JL, et al. Fasting plasma ghrelin concentrations 6 months after gastric bypass are not determined by weight loss or changes in insulinemia. Obes Surg. 2004;14(9):12081215.

135. Morínigo R, Casamitjana R, Moizé V, et al. Short-term effects of gastric bypass surgery on circulating ghrelin levels. Obes Res. 2004;12(7):11081116.

136. Holdstock C, Engström BE, Ohrvall M, et al. Ghrelin and adipose tissue regulatory peptides:effect of gastric bypass surgery in obese humans. $J$ Clin Endocrinol Metab. 2003;188(7):3177-3183.

137. Morínigo R, Lacy AM, Casamitjana R, et al. GLP-1 and changes in glucose tolerance following gastric bypass surgery in morbidly obese subjects. Obes Surg. 2006;16(12):1594-1601.

138. Näslund E, Bogefors J, Skogar S, et al. GLP-1 slows solid gastric emptying and inhibits insulin, glucagon, and PYY release in humans. Am J Physiol. 1999;277(3 Pt 2):R910-R916.

139. Hickey MS, Pories WJ, MacDonald KG Jr, et al. A new paradigm for type 2 diabetes mellitus:could it be a disease of the foregut? Ann Surg. 1998;227(5):637-643.

140. Korner J, Inabnet W, Conwell IM, et al. Differential effects of gastric bypass and banding on circulating gut hormone and leptin levels. Obesity (Silver Spring). 2006;14(9):1553-1561.

141. Anini Y, Brubaker PL. Role of leptin in the regulation of glucagon-like peptide-1 secretion. Diabetes. 2003;52(2):252-259.

142. Gutzwiller JP, Göke B, Drewe J, et al. Glucagon-like peptide-1:a potent regulator of food intake in humans. Gut. $1999 ; 44(1): 81-86$.

143. Williams DL, Baskin DG, Schwartz MW. Leptin regulation of the anorexic response to glucagon-like peptide-1 receptor stimulation. Diabetes. 2006;55(12):3387-3393.

144. Morton GJ, Blevins JE, Williams DL, et al. Leptin action in the forebrain regulates the hindbrain response to satiety signals. J Clin Invest. 2005;115(3):703-710.

145. Wickremesekera K, Miller G, Naotunne TD, et al. Loss of insulin resistance after Roux-en-Y gastric bypass surgery:a time course study. Obes Surg. 2005;15(4):474-481.

146. Clements RH, Gonzalez QH, Long CI, et al. Hormonal changes after Roux-en Y gastric bypass for morbid obesity and the control of type-II diabetes mellitus. Am Surg. 2004;70(1):1-4.

147. Kaiyala KJ, Prigeon RL, Kahn SE, et al. Obesity induced by a high-fat diet is associated with reduced brain insulin transport in dogs. Diabetes. 2000;49(9):1525-1533.

148. Kaiyala KJ, Prigeon RL, Kahn SE, et al. Reduced beta-cell function contributes to impaired glucose tolerance in dogs made obese by highfat feeding. Am J Physiol. 1999;277(4 Pt 1):E659-E667. 